\title{
Value of Aspect Differences Towards Theory of Planned Behavior Between Hospital Personnels of a Private Hospital in Mataram
}

\author{
Nadia Sutanto and Made Aswina Putra \\ Faculty of Psychology \\ Universitas Surabaya
}

\begin{abstract}
Medical staffs are considered to be people who should be able to set an example to the public, concerning the way life should be lived. The design of this research was that of a comparative study model, which compared aspects of the Theory of Planned Behavior from three groups of medical staff subjects. The research was aimed at providing a basic picture of the obesity of the medical staff in a private hospital in Mataram, West Nusa Tenggara, Indonesia. Besides this, it also searched for differences in perceptions, based upon the Theory of Planned Behavior. The research results indicated that, of the aspects of Theory of Planned Behavior, it was only those of Intention, Subjective Norms, and Attitudes Toward Behavior, which showed any differences between the subject groups, that is, the groups of those suffering obesity demonstrated an intention to perform, and a positive attitude towards, behavior aimed at reducing bodily weight.
\end{abstract}

Keywords: obesity, hospital medical staff, aspects of theory planned behavior

Tenaga kesehatan dianggap mampu memberikan contoh kepada masyarakat mengenai pola makan yang sehat. Desain penelitian ini adalah model studi perbandingan, membandingkan aspect Theory of Planned Behavior dalam tiga kelompok tenaga kesehatan. Penelitian bertujuan untuk menyediakan gambaran dasar dari obesitas tenaga kesehatan di sebuah rumah sakit di Mataram, Nusa Tenggara Barat, Indonesia. Selain itu, penelitian ini juga menyelidiki perbedaan persepsi berdasarkan Theory of Planned Behavior. Hasil peneltiian mengindikasikan bahwa, dari seluruh aspek Theory of Planned Behavior, hanya aspek Intention, Subjective Norms, dan Attitudes Toward Behavior yang menunjukkan perbedaan antara kelompok subjek, yaitu kelompok dengan obesitas menunjukkan intensi aksi dan sikap positif terhadap perilaku bertujuan mengurangi berat badan.

Kata kunci: obesitas, tenaga rumah sakit, aspek theory planned behavior

Obesity is a quite long-standing problem, not only in developed countries, but also even in developing countries. Based on the data which has been collected, $28 \%$ of the population of the United States suffers from obesity, in Germany being $21 \%$, in Canada $15 \%$, in Egypt 25\%, in Iran 10\%, and in Saudi Arabia 17\% (Prentice, 2006). Obesity is a problem which must be controlled, particularly that amongst children. Earlyonset childhood obesity, if not immediately overcome, may be carried through into adulthood, and become increasingly difficult to control. (Simajuntak \& Siregar, 2012). According to World Health Organization (WHO) data, it has been found that, of children aged between 517 years, some ten percent are recorded as being obese.

Correspondence concerning this article should be addressed to Nadia Sutanto, Faculty of Psychology Universitas Surabaya, Jalan Raya Kalirungkut, Surabaya 60293. Email: nadia@staff.ubaya.ac.id
Data from the Indonesian Ministry of Health (Kementerian Kesehatan Republik Indonesia - Kemenkes RI) shows that the percentage of children suffering obesity is, in general, 9.5\%, whilst for female children being $6.4 \%$.

According to research by Malnick and Kobler, in a comparison study of the periods 1976-1980 and 19992000 , it was discovered that there had been a rise in the levels of the percentage of overweight people, of $18.5 \%$, that is, from $46 \%$ it became $64.5 \%$. The percentage of people with obesity had undergone a two-fold increase, to $30 \%$. This discovery was also supported by the WHO, which in 2003 found that there were 300 million sufferers of obesity at that time, and calculated that, in 2015, that total would increase to 700 million (Putra, 2011). The increase in the percentage of obesity was actually followed by an increase in the occurrence of cardiovascular disease, in the world. 
Basically, obesity occurs because of an imbalance between the intake of energy, versus the amount of energy expended in daily activities. This results in an excessive intake of calories, which later are stored in the body in the form of fat (Horvath, Castro, Kops, Malinoski, \& Friedman, 2014; Kumar, 2012; Simajuntak $\&$ Siregar, 2012). If categorized, obesity may occur because of two factors, inheritance factors, which may be sub-divided into genetic and physical factors, and external factors.

Genetic factors are the most important, and are the determinant as to whether a person succumbs to obesity easily, or not. According to Whitney and Genarty, a child has a greater tendency to become obese if just one of his or her parents has a family history of obesity, as opposed to children, neither of whose parents has such a family history (Whitney, Cataldo, \& Rolfes, 1990). Physical factors are those of gender and age. These two factors may be said to have an influence because, indirectly, they will influence the types of activities undertaken, and the types of food consumed, by a person. According to Dietz (as cited in Manurung, 2008), the ages of vulnerability for a person to suffer the onset of obesity are from birth to the teenage years, also known as the period of development. This is because, during that period, a person tends to require a high calorific intake, and, if this is not offset by physical activity, it will cause obesity (Manurung, 2008). If obesity at these ages is not well managed, there may be the potential for it to be carried forward into adulthood, and become more difficult to manage.

The external factors are influenced by the person him or herself, as well as by others around him or her. The external factors influenced by the person him or herself cover life patterns, such as types of daily activities, frequency of exercise, types of food normally consumed, times of eating, amount of food consumed, and the personality of the obesity sufferer. The factors arising from others around the sufferer, cover, inter alia, the pattern of parental upbringing, the societal environmental outlook concerning the ideal body form, environmental cultural factors, and the social environment (Manurung, 2008).

Obesity is a very dangerous condition, as it is capable of becoming the trigger for several diseases, and may subsequently cause complications. In several pieces of research, it is said that if the body weight of an obese sufferer of hypertension is reduced, his or her blood pressure may also be reduced (Aucott et al., 2005; Hermawan, 1991; Kotchen, 2010). Ibarra also stated that there are several frequent causes of problems for sufferers of obesity, such as high blood pressure (hy- pertension) and dilation of the ventricular vessels, as a result of an increase in the volume of blood, of stroke, or inappropriate activities of the heart (Ibarra, 2009). According to Ibarra, these problems may later cause disruptions to the blood flow, which then cause heart attacks for sufferers of obesity. Aside from diseases and problems related to the cardiovascular system, suffers of obesity often experience accumulations of fat in the chest and abdominal cavities, impeding the activities of the lungs, and later on disrupting the respiratory system, as well as causing shortness of breath and sleep apnea (Hermawan, 1991; Olsen, Wiklund, Lonroth, \& Olbers, 2012; Rabec, Ramos, \& Veale, 2011).

Besides having physical impacts, obesity can also influence the psychological health of a person. Normally, obese people will have poor body image, related to their evaluation of their bodily form (Putri, 2012). As well, sufferers of obesity, particularly juveniles, will tend to feel dissatisfaction with their bodily image (Sarwer, Thompson, \& Cash, 2005; Tarigan, Hadi, \& Julia, 2005). This feeling of dissatisfaction, for sufferer of obesity, may bring about the appearance of feelings of depression, and a tendency towards selfblame, resulting from feelings of inability to exercise self-control, later leading to a tendency towards suicidal feelings (Elovainio et al., 2009; Fatimah, 2014; Onyike, Crum, Lee, Lyketsos, \& Eaton, 2003; Roberts, Deleger, Strawbridge, \& Kaplan, 2003; Zeller, Purtill, Jenkins, \& Ratcliff, 2013).

There is a variety of points of view on, and labels applied to, obesity and obese persons, by society. Often, society imposes negative stigma on people suffering obesity, calling them lazy, awkward, undisciplined, dirty, and unattractive (Puhl \& Heuer, 2010). This negative view of obesity sufferers often causes the manifestation of similarly negative behavior, from those in their environment. One of the types of negative behavior often found expressed by society is bullying and verbal abuse. Based upon research conducted in America, there has been an increase of $66 \%$ in cases of discrimination towards obesity sufferers, and this now has a significance equal to that of cases of discrimination on the basis of race in that country (Puhl \& Heuer, 2010). According to Puhl and Heuer, these cases of discrimination occurred because society was of the opinion that the condition of these obese people was entirely their own fault, and the assumption that, receiving verbal abuse and bullying, these obesity sufferers would be motivated to reduce their weight.

Discrimination is also experienced by obese people in the workplace. This discrimination occurs because 
of the stigma that obesity sufferers are lazier, have no work motivation, and their interpersonal abilities are worse than those of other workers (Nowrouzi et al., 2015). The majority of sufferers of obesity and overweight are aware of the condition of their bodies, and understand the causes of the onset of said condition, however quite a number do not feel that the condition can endanger health. This misperception regarding the danger of their bodily condition is held because they do not feel there is a direct impact upon them, attributeable to obesity (Annisa, Indriasari, \& Yustini, 2014).

In accordance with the Indonesian Government Regulation No. 32 of 1996, to be recognized legally as a member of medical staff, a person needs a formal educational background in the field of health. Because of this, a medical staff member must comprehend the concept of a healthy lifestyle, so that he or she is capable of handling this matter, and of becoming an example to the public. In fact, there are still medical staffs who lead an unhealthy life. Several unhealthy patterns of living, often still found amongst medical staffs, are smoking, the consumption of alcohol, and eating patterns so disordered that they result in excessive body weight, often reaching the stage of obesity. In one piece of research performed in Jamaica, it was discovered that $33 \%$ of medical staff in the institute involved had body weight classifiable as obese, there were $43 \%$ overweight, with only $24 \%$ having a normal body weight (Bourne, Glen, Laws, \& Kerr-Campbell, 2010). Besides this, in the same piece of research, more than $15 \%$ of the subjects drank alcohol and did not play sport, and 3\% smoked. In another piece of research, performed in Kenya, it was also discovered that many sufferers of obesity were medical staff (Ondicho, Omondi, \& Onyango, 2016).

The private hospital in Mataram is a well known hospital, located in the centre of the city of Mataram. Within the environs of the private hospital, no medical staff was observed smoking, however there were several medical staff members whose bodily posture categorized them as overweight, and having unhealthy eating habits, such as the eating of food with large amounts of carbohydrates, and oily food. It is concerning, as this could be a bad example for patients being treated in the hospital, particularly those being treated for obesity.

There are several methods which may be used to overcome obesity. The generally used method is by regulating dietary patterns, and routinely playing sports (Iffah, 2011; Mappaompo, 2010). These aside, there is supportive behavior therapy intervention, which may also assist in alteration of the behavior of obesity suf- ferers. There are various theories to explain the behavior patterns of a person. In this research, the theory of planned behavior was used, to formulate the research's problem formula.

The problem formula in this research is exactly how the model aspects of the Theory of Planned Behavior, those being attitudes toward behavior, subjective norms, and perceived behavioral controls, are related to the condition of obesity, found within the medical staff members of the private hospital in Mataram.

\section{Goals of the Research}

Based upon the problem formula, the goal of this research was to obtain a picture of every aspect within the Theory of Planned Behavior of medical staff and aides, in the private hospital in Mataram.

\section{Research Benefits}

It was hoped that the results of this research would be able to give a picture of every aspect of the Theory of Planned Behavior of the medical staff in the hospital concerned, so that, in the future, it would be able to help provide directions to, and training of, the personnel still holding incorrect beliefs concerning obesity. Other benefits would be to raise the standards of service in the hospital concerned, particularly towards patients suffering obesity. Besides this, it was hoped the research might become material for reflection amongst the subjects, to enable an increase in their awareness of their bodily shapes.

\section{Definition of Obesity}

When sought in the online Great Indonesian Language Dictionary (Kamus Besar Bahasa Indonesia $K B B I$ ), obesity was defined as a condition wherein there is an accumulation of excessive fat within the body (Sunendar, 2016). If studied in the Oxford English Dictionary (OED), obesity is explained to be a condition where (bodily) fat is excessive, or where a person has excessive bodily weight (Oxford Dictionary of English ((3rd ed.)), 2010). Based upon these definitions, it may be concluded that obesity is a condition wherein the body is too fat, or a condition wherein fat is held to excess within the body.

According to the definition from the WHO, obesity is a condition of excessive bodily fat build-up. In determining whether a person has become obese, it is necessary to calculate the comparison between his or her body weight and the square of his or her height. 


$$
\text { Body Mass Index }=\frac{\text { Body Mass (in kg.) }}{(\text { Body Height (in m.) })^{2}}
$$

This method is known as the method of calculating the Body Mass Index. Based upon the WHO standard, a person may be categorized as obese if he or she has a body mass index of 30 or more (The International Classification of adult underweight, overweight and obesity, according to Body Mass Index, n.d.). Further clarification can be seen in Table 1, which explains the WHO classification regarding bodily condition, on the basis of the Body Mass Index.

At variance with the WHO, the Indonesian Ministry of Health has determined a different standard, in regard to Body Mass Index categories. The Indonesian Ministry of Health has determined that the categories related to Body Mass Index should be five, these being seriously underweight, somewhat underweight, normal, somewhat overweight, and seriously overweight. These divisions were determined on the basis of clinical experience and research conducted in a number of developing countries (Pedoman praktis memantau status gizi orang dewasa (A Practical Guide to Monitoring the Nutritional Status of Adults), 2011). For fur-

\section{Table 1}

\section{Body Mass Index (BMI) Classifications}

\begin{tabular}{lc}
\hline \multicolumn{1}{c}{ Classifications } & BMI \\
\hline Underweight & $<18.50$ \\
Normal & $18.50-24.99$ \\
Overweight & $25.00-29.99$ \\
Obese I & $30.00-34.99$ \\
Obese II & $35.00-39.99$ \\
Obese III & $>40.00$ \\
\hline $\begin{array}{l}\text { Note. Classifications according to the WHO (The International Classification } \\
\text { of Adult Underweight, Overweight and Obesity, According to BMI, n.d.) }\end{array}$
\end{tabular}

Table 2

BMI Classifications, according to The Indonesian Ministry of Health

\begin{tabular}{lcc}
\hline & \multicolumn{1}{c}{ Category } & IMT \\
\hline Underweight & $\begin{array}{l}\text { Extremely underweight } \\
\text { Somewhat underweight }\end{array}$ & $<17.0$ \\
& & $17.0-18.4$ \\
Normal & Somewhat overweight & $25.1-27.0$ \\
Overweight & Extremely overweight & $>27.0$ \\
\hline $\begin{array}{l}\text { Note. BMI in Indonesian is Index Massa Tubuh (IMT). Classification } \\
\text { according to the Indonesian Ministry of Health - Kementerian Kesehatan } \\
\begin{array}{l}\text { Republik Indonesia (A Practical Guide to Monitoring the Nutritional Status } \\
\text { of Adults, 2011) }\end{array}\end{array}$
\end{tabular}

ther clarification, see Table 2 . In this study, the researchers used the classification published by the Indonesian Ministry of Health as a reference. This was done for one simple reason, that being this research was conducted in Indonesia, so that the reference published by the Indonesian Ministry of Health should be more suitable to illustrate the conditions of the subjects.

\section{Causative Factors for Obesity}

Basically, obesity occurs because of an imbalance between the input of calories and the calories used in daily activities. If this were to be formulated within the laws of thermodynamics, it may be said that there is an excess of energy in the body, as a result of the consumption of energy in the body being less than maximal (Manurung, 2008). This energy, in the form of the residue of calories within the body, is then stored by the body in the form of layers of fat (Sediaoetama, 2008).

The imbalance between the intake of calories and the calories used by the body may be caused by a number of things. The factors occasioning the occurrence of obesity are, inter alia:

Biological factors. Genetic factors are related to inheritance from parents, and whether there is a history of obesity with the parents. As explained by Whitney and Genarty (Whitney et al., 1990), obesity is an inheritable condition. A child with parents having a history of obesity has a higher possibility of becoming an obesity sufferer, compared to a child with history of obesity in his or her background. Although this is the case, underlying factors do not absolutely determine that a person will suffer obesity. The genes which may influence the occurrence of obesity are the gene INSIG2 (Insulin Induced Gene 2), which is responsible for impeding the synthesis of fatty acids and cholesterol, the gene FTO (Fat Mass and Obesity - associated protein/Alpha-Ketoglutarate-Dependant-Dioxygenase FTO), located on human chromosome 16, which is active in the hypothalamus, and is responsible for the regulation of hunger; the obesity gene which encodes the protein LEPTIN, which also functions to regulate hunger, and the burning of fat (Moleres et al., 2011; Skelding et al., 2010; Walley, Blakemore, \& Froguel, 2006).

Gender and age are also factors influencing the occurrence of obesity in a person. Certainly gender and age indirectly impact the eating patterns of a person, because of there being differences in the need for the intake of nutrients, and the types of food which can be digested. Besides having an influence upon eating 
patterns, according to Arisman (2004) there is a difference in the prevalence of obesity between men and women, According to Arisman, women have a greater chance of suffering obesity than men (Arisman, 2004). Also, aside from this, according to Dietz (Virgianto, 2005), the age range for the onset of obesity is from birth to the teenage years. This can be because, during that period, children require a high intake of nutrients and calories, which they need to their period of development. If not handled immediately, teenage obesity can continue into adulthood, and become even more difficult to handle (Manurung, 2008).

Although it is said to have an influence, in fact the influence of the genetic factor is a smaller one, compared to that of the environment. Although a person may have a genetic condition, and tend easily to become obese, however an ordered regimen of physical activity and the controlled intake of nutrients can reduce the chance of, indeed even prevent the occurrence of obesity.

Environmental factors. The socioeconomic level of a person will have an influence upon the type of foods consumed. From one piece of research, conducted in midtown Manhattan, New York, it was discovered that there is an obvious reverse relationship between the socioeconomic level of a person, and the size of the chance of obesity (Manurung, 2008). This is caused by people from a low economic class generally having an unbalanced pattern of eating, a focus on carbohydrates in the daily diet, this causing a high intake of calories which are then absorbed by the body (Manurung, 2008).

Although this is the case, research performed by Octari indicated that the factor of the lack of economic means is not always the prime cause of obesity. Octari discovered that the majority of sufferers of obesity came from the group classified as 'economically able to cope' (Octari, Liputo, \& Edison, 2014).

Aside from the socio-economic factor, patterns of living also have an important role in regulating the number of calories taken into the body every day. What is meant by patterns of living covers: physical activity, type and amount of food consumed daily, as well as the frequency one takes exercise (Manurung, 2008). Physical activities, together with frequency of exercise, are the determinants of the number of calories used by a person, whilst eating patterns are the determinants of the number of calories being taken into the body (Hidayati, Irawan, \& Hidayat, 2009).

Culture also has an indirect role in the patterns of life of a person. Differences in culture can influence the types of foodstuffs eaten by a person, and the nu- tritional value of the food itself. In Indonesia, a number of foods containing carbohydrates, besides rice, are thought to be appropriate for consumption as the principle sources of carbohydrates in nutrition. One of these sources is noodles, another is potatoes. Culture is also a guide for society, as to what types of food are suitable to be eaten, and what are not, those normally being subject to food taboos (Kristina, 2010). Besides this, the culture of the lifestyle of people in the cities is different to that of those living in villages. The lifestyle in the villages still involves many physical activities, whereas those in the cities tend to engage in a minimum amount of physical activity, as a result of having motorized transport and spending spare time in activities not involving physical exertion, but watching shows and playing games with the children, in a city environment (Istiwamah, Sirajuddin, \& Indriasari, 2013).

These days, particularly in the big cities, something has developed which is known as a sedentary lifestyle. A sedentary lifestyle is one dependent upon the practicality of helpful devices, so that the physical activities of people are at a minimum. The minimality of physical activity is not balanced by the types of food consumed by people in the large cities, who are fond of eating 'junkfood', because of its greater practicality. This is a factor supporting the occurrence of obesity (Manurung, 2008). 'Junkfood' is food which is not conducive to good health, because it contains high amounts of calories and cholesterol, not counterbalanced by having other nutritional values, as required by the body (Wahyuni, 2013).

\section{The Impacts of Obesity}

Physical impacts. Several physical constraints are in general experienced by sufferers of obesity, including breathing difficulties, physical functioning difficulties, cardiovascular problems and cancer (Villareal, Apovian, Kushner, \& Klein, 2005). Breathing difficulties experienced by sufferers of obesity tend to occur because the diaphragm is obstructed by fat, reducing the maximum capacity of the lungs, and causing sufferers of obesity to be unable to draw breath as they should. The reduction in the ability to breathe properly will subsequently have an impact upon the concentration of oxygen in the bloodstream, and cause a condition known as the obesity-hypoventilation syndrome (Gibbons, 2013; Parameswaran, Todd, \& Soth, 2006; Villareal et al., 2005).

Aside from in the abdomen, the accumulation of fat in the neck may also restrict the breathing flow, and ca- 
use obstructive sleep apnoea (Gibbons, 2013; Schwartz et al., 2008). Sleep apnoea is a problem in the form of stoppages in the breathing process when sleeping, as a result of the narrowing of the breathing passages, and causes a condition whereby the brain is startled into wakefulness. This disturbance often occurs for short periods, so as not to be noticed by the sufferer, apart from the brain being momentarily startled into wakefulness. Sleep apnea itself is considered to be dangerous, because apart from causing troubled sleep, and a sensation of choking when asleep, sleep apnea also causes an increase in brain activity and blood flow, and may eventually cause the development of disruptions to the cardiovascular system, such as stroke, high blood pressure and an abnormal heart beat (Jean-Louis, Zizi, Clark, Brown, \& McFarlane, 2008; Leung \& Bradley, 2001).

Psychological impacts. Besides causing problems to physical health, obesity in children and teenagers also has quite a large impact upon psychological health. According to Sutjijoso and Zarviel (2009), children and teenagers who suffer obesity often have a troubled self-image, low self esteem, and depression. These psychological disturbances occur as a result of negative responses from people in the environments of the sufferers, which are manifested in the form of ridicule or humiliation from colleagues, or teachers, in school environment. These psychological problems, if they continue into the future, may prompt the obesity sufferer to depend upon smoking and drinking as a form of coping (Sutjijoso \& Zarfiel, 2009).

According to French, the majority of teenagers who suffer obesity have low self-esteem concerning their bodies. Often, teenagers who suffer from obesity consider their bodily shape to be unattractive to the opposite sex, so that they often experience difficulties in meeting partners (French, Story, \& Perry, 1995). The research conducted by Delima added information about the low level of self-esteem of sufferers of obesity, i.e. that females who suffer obesity have a feeling of apprehension as to whether they will be able to attract the opposite sex (Delima, 2013). This low level of self-esteem of obesity sufferers may later cause them difficulties in self-actualization, so they will also demonstrate poor performances in socialization, or in employing their abilities to the maximum extent possible (Ginting, 2011).

\section{Forms of Intervention}

There are several methods which may be used by obesity sufferers in order to reduce their bodily weight, to achieve a normal standard of Body Mass Index. One of these methods commonly employed is the control of eating patterns. According to Sargowo, regulation of eating patterns and the avoidance of foods with a high fat content is needed (Sargowo \& Andarini, 2011). Apart from this, it has also been found that a dietary programme (regulation of eating patterns) for the sufferer of obesity is able to reduce bodily weight more effectively, compared to the taking of exercise. Nonetheless, the problems which often arise with the use of the diet method are that when the target bodily weight is achieved, the subject may return to the old pattern of eating, i.e., unregulated times of eating, as well as consumption of food and drink containing large amounts of sugar, as a form of reward, causing bodily weight to rise again (Iffah, 2011). According to Pi-Sunjer (as cited in Iffah, 2011), there are diet types which can be followed by obesity sufferers, inter alia:

(1) The high-fiber diet, that is a diet pattern prioritizing the consumption of food containing amounts of fiber, so as to reduce, even to prevent, the absorption of energy-producing elements, particularly carbohydrates.

(2) The low-calorie diet, that is the prioritization of foods containing the elements required by the body, and reducing the intake of foods containing energyproducing elements.

(3) Complete fasting, without any intake of foodstuffs, and the intake of water and electrolytes through drinking. Bodily energy will be produced from stored body fat. It should be noted that this type of diet requires close supervision by a doctor.

Besides by closely watching eating patterns, obesity can also be overcome by routine exercise. Exercise can burn fat, and prevent the accumulation of lactic acid in the body (Mappaompo, 2010). This accumulation of fat is caused by the excessive intake of carbohydrates, which are then stored as energy reserves, in the form of fat (Manurung, 2008). According to Iffah (2011) exercise is useful to burn fat, to a level $30 \%$ higher than that of moderate activity, and this burning may continue for some time after the exercise is taken. Besides this, it has been found that the implementation of a diet will be more effective if carried out in conjunction with routine exercise. Mappaompo (2010) stated that the most effective form of exercise to reduce body weight is aerobic exercise. Aerobic exercises are activities such as walking, jogging, swimming and playing basketball.

Although these forms of intervention have been found to be of use, changing the behavior patterns of a person suffering overweight is a difficult matter. Because of this, the assistance of behavioral intervention 
therapies is required. One of these is the method related to the Theory of Planned Behavior.

\section{The Theory of Planned Behavior}

The Theory of Planned Behavior is one originally put forward by Ajzen and Fishbein, in 1980, under the name of the Theory of Reasoned Action, to explain the relationship between attitude and behavior. Originally, Ajzen and Fishbein were of the opinion that behavior is something which is voluntary in nature. Ajzen and Fishbein later revised their theory, after realizing that a particular behavior is not fully voluntary in nature, and altered the name to the Theory of Planned Behavior.

According to Ajzen, there are three factors which may influence the emergence of a behavior. These factors are Attitude Toward Behavior, Subjective Norms, and Perceived Behavioral Control (Ajzen, 2006).

(1) Attitude Toward Behavior, according to Ajzen, is the evaluation by a person of a pattern of behavior. This evaluation is basically influenced by behavioral beliefs, or convictions held by a person related to the virtue or vice of a behavior, and an evaluation regarding the impact caused by that behavior upon themselves, and his or her environment (Ajzen, 2006; Wahyono, 2013).

(2) Subjective Norms, are the perceptions of a person regarding social pressures, which prompt the person to be involved in a behavior. According to Ajzen, subjective norms will be influenced by normative be- liefs, or the convictions of a person concerning the behaviors expected in his or her environment. Besides normative beliefs, the motivation to follow the demands of that environment (the motivation to comply) will also influence the strength of the subjective norms in influencing the manifestation of any behavior (Ajzen, 2006; Wahyono, 2013).

(3) Perceived Behavioral Control refers to the perceptions of a person regarding his or her ability to perform a behavior. This perceived behavioral control will be influenced by control beliefs and the power of each control factor. What is meant by control beliefs is the perception of a person related to the factors which may support or hinder them in performing a behavior (control factors) (Ajzen, 2006; Wahyono, 2013). From the Theory of Planned Behavior viewpoint, these three factors will later influence the Intention regarding the behavior. Intention is considered to be a factor bridging the emergence of a behavior. Positive responses from these three factors later give rise to positive intention regarding a behavior, and the converse also applies (Ajzen \& Fishbein, 1980).

\section{Medical Staff}

Based upon Government Regulation No. 32 of 1996 (Peraturan Pemerintah No. 32 Tahun 1996), medical staff means people involved in the provision of health services, and who have experience in the relevant field of education. In that regulation, it is also explained that medical staffs are classified into three types (see Table 3).

Table 3

Classification of Medical Staff

\begin{tabular}{llll}
\hline \multicolumn{1}{c}{ Medical Staff } & \multicolumn{1}{c}{ Section } & \multicolumn{1}{c}{ Medical Staff } & Section \\
\hline Professional level staff & $\begin{array}{l}\text { Doctor } \\
\text { Dentist }\end{array}$ & Physical therapeutical staff & $\begin{array}{l}\text { Physiotherapist } \\
\text { Occupational therapist } \\
\text { Speech therapist }\end{array}$ \\
& Nurse & & Radiographer \\
Mursing staff & Midwife & Medical technical staff & Radiotherapist \\
& Pharmacist & Dental technician \\
Pharmacy staff & Pharmaceutical analyst & Electromedical technician \\
& Assistant pharmacist & Health analyst \\
& Health epidemiologist & Optical refractionist \\
& Health entomologist & Prosthetic orthotic \\
& Health microbiologist & Transfusion technician \\
& Health extension officer & & Medical recorder \\
& Health administrator & Nutritional staff & Nutritionist \\
& Sanitarian & Dietician
\end{tabular}




\section{Method}

\section{Research Variables}

The Theory of Planned Behavior model means the values achieved from each aspect. (1) Variable I: Intention; (2) Variable II: Attitude Toward Behavior; (3) Variable III: Subjective Norms; (4) Variable IV: Perceived Behavioral Control; (5) Variable V: Body Mass Index Category. Body Mass Index Category is the classification into which people are put, according to the classification standards of the Indonesian Ministry of Health. The group of subjects was divided into three categories, i.e., normal body weight, slightly overweight and seriously overweight.

\section{Population and Data Collection Techniques}

The population for the research was the entire medical and assistant medical staff working at the private hospital in Mataram. Sampling was conducted using the incidental sampling method, by distributing surveys to the heads of each post and section, which were

Tabel 4

Subject Distribution by Gender, Based on BMI Category

\begin{tabular}{cccc}
\hline & Subject & $n$ & $\%$ \\
\hline Normal BMI & Male & 25 & 52 \\
& Female & 3 & 6 \\
Moderately overweight BMI & 22 & 46 \\
& Male & 12 & 25 \\
Female & 7 & 15 \\
Seriously overweight BMI & 5 & 10 \\
& Male & 11 & 23 \\
Female & 2 & 4 \\
& & 9 & 19 \\
\hline
\end{tabular}

Table 5

Subject Distribution by Marital Status, Based on BMI Category

\begin{tabular}{ccr}
\hline \multicolumn{1}{c}{ Subject } & $n$ & \multicolumn{1}{c}{$\%$} \\
\hline Normal BMI & 25 & 52.08 \\
Single & 7 & 14.58 \\
Married & 16 & 33.33 \\
Widow/widower & 2 & 4.17 \\
Moderately overweight BMI & 12 & 25.00 \\
Single & 5 & 10.42 \\
Married & 6 & 12.50 \\
Widow/widower & 1 & 2.08 \\
Seriously overweight BMI & 11 & 22.92 \\
Single & 3 & 6.25 \\
Married & 7 & 14.58 \\
Widow/widower & 1 & 2.08 \\
\hline
\end{tabular}

later disseminated to the members of the relevant posts and sections.

The data collection process was divided into two stages, the distribution of demographic surveys to collect data of the Body Mass Index categories of all medical staffs, later followed up by the collection of data regarding Theory of Planned Behavior (Intention, Attitude Toward Behavior, Subjective Norms and Perceived Behavioral Control), related to the obesity and eating patterns of the subjects, after permission was obtained through the use of informed consent forms.

\section{Research Design and Data Analysis Techniques}

The design of the research used was the comparative study model, that is the comparison of the differences in aspects of Theory of Planned Behavior within the three groups of subjects, i.e., the categories of normal weight, moderately overweight and seriously overweight, from all medical staffs and their aides. The data obtained was analyzed using SPSS software. Firstly, the data was tested as to its reliability, and then each aspect was tested as to its normality, using the Kolmogorov-Smirnov method, followed by testing as to homogeneity.

\section{Results}

\section{Conduct of the Research}

The data collection process at the private hospital in Mataram, was conducted over a period of three weeks, comprising one week for the process of data collection at initial investigation level, followed by two weeks for data collection, using the Theory of Planned Behavior surveys.

From the initial information obtained from the hospital, there were 300 medical staffs working there. In the initial data collection, regarding height and bodily weight, of the 300 surveys distributed, only 233 were returned. From this data, it was discovered that 29 people were in the category of seriously overweight, 31 were in the category of moderately overweight, 171 were of normal weight, and two were underweight.

The authors then distributed the surveys concerning the Theory of Planned Behavior to 116 persons, these being the 56 medical staffs with normal body weight, plus the 60 classified as overweight (moderately and seriously). Of the 116 questionnaires distributed, only 71 were returned. The details here were that 23 were returned blank, 23 were from the subject categorized 
as overweight, and 25 came from subjects in the category of normal weight. Eventually, 48 persons were used as the research sample.

\section{Description of the Research Subjects}

Table 4 indicates that the female medical staffs that were overweight numbered more than the overweight males. Although this was so, if this is viewed in more detail, the number of males moderately overweight was in the majority, whilst the category of seriously overweight was dominated by females. The majority of those overweight at the private hospital in Mataram, were married, comprising $27 \%$ of the sample total (Table 5). Most of the sufferers of obesity were aged between 21-40 years. From the total sample of 48 persons, the ages of $39.5 \%$ were between 21 and 40 years of age. From this total, it appeared that sufferers of obesity were to be found in the range of people aged 31 to 40 years, these being $22.0 \%$ of the sample total (see in Table 6).

\section{Validity}

Construct validity refers to how exactly an idea or theory is changed to become a measurement instrument capable of describing reality (Trochim, 2006). Table 7 indicates that the surveys fulfilled the aspects of translation validity, because the items in them were constructed after consideration of the Theory of Planned Behavior, as a reference (content validity). The blueprint and items may be viewed (on request).

\section{Reliability}

Table 8 shows that the Alpha-Cronbach values of each aspect are very reliable, because they are far greater than .6. Therefore, the writers felt that it was not necessary to conduct item elimination.

\section{Normality Testing}

If considered from the viewpoint of KolmogorovSmirnov significance values, only the Subjective Norms aspects have values greater than .05 . This means that it is only the Subjective Norms values which have normal data distribution (see Table 9).

Table 6

Subject Distribution by Age, Based on BMI Category

\begin{tabular}{ccr}
\hline Subject & $n$ & \multicolumn{1}{c}{$\%$} \\
\hline Normal BMI & 25 & 52.08 \\
18-20 years & 0 & 0.00 \\
21-30 years & 14 & 29.17 \\
31-40 years & 10 & 20.83 \\
41-50 years & 1 & 2.08 \\
$51-60$ years & 0 & 0.00 \\
< 60 years & 0 & 0.00 \\
Moderately overweight BMI & 12 & 25.00 \\
18-20 years & 0 & 0.00 \\
21-30 years & 5 & 10.42 \\
31-40 years & 6 & 12.50 \\
$41-50$ years & 0 & 0.00 \\
$51-60$ years & 0 & 0.00 \\
< 60 years & 1 & 2.08 \\
Seriously overweight BMI & 11 & 22.92 \\
18-20 years & 1 & 2.08 \\
21-30 years & 3 & 6.25 \\
$31-40$ years & 5 & 10.42 \\
$41-50$ years & 1 & 2.08 \\
$51-60$ years & 1 & 2.08 \\
<60 years & 0 & 0.00 \\
\hline
\end{tabular}

\section{Table 7}

Blueprint of Inquiry

\begin{tabular}{ll}
\hline \multicolumn{1}{c}{ Variable } & \multicolumn{1}{c}{ Indicator } \\
\hline Intention & $\begin{array}{l}\text { Intention is the result of consideration of other factors, and illustrates the readiness of a } \\
\text { person to perform an activity, in this case to make an effort to reduce body weight. }\end{array}$ \\
Attitude Towards & $\begin{array}{l}\text { This is the attitude and evaluation of a person regarding a pattern of behavior. In this case, it } \\
\text { is an illustration of the attitude of a subject concerning the effort to reduce bodily weight. }\end{array}$ \\
Subjective Norms & $\begin{array}{l}\text { These are the perceptions of a subject regarding the social pressures experienced, related to a } \\
\text { particular behavior. In this case, it is the perception of a subject regarding the social pressure } \\
\text { he or she experiences, related to efforts made to reduce weight. }\end{array}$
\end{tabular}

Perceived Behavioral This is the perception of a person concerning ability to control his or her behaviour. In this Control case, it is the ability to control eating behavior, in the face of certain conditions. 


\section{Homogeneity Testing}

In Table 10 shows homogeneity testing. If considered from the viewpoint of significance values, only the Perceived Behavioral Control aspect has a value greater than .05 , meaning that this aspect is homogeneous. In regard to the aspect of Intention, the Attitude Toward Behavior and Subjective Norms are concluded to be non-homogeneous (heterogeneous). Because there was no normal and homogeneous data, all aspects were tested using Kruskal-Wallis non-parametric methods.

\section{t-test}

Based upon the results of normality and homogeneity testing, it was found that the four aspects showed no characteristics of normality and homogeneity, so that all aspects were tested using the non-parametric Kruskal-Wallis method (see Table 11).

Based upon the results of the non-parametric t-test, using the Kruskal-Wallis method, there was a significance of .05 . If considered from the viewpoint of their significance values, the aspects of Intention, Attitude Toward Behavior and Subjective Norms have lower values than the level of significance, so that it may be concluded that there are differences in the values of the aspects of Intention, Attitude Toward Behavior, and Subjective Norms, between subject groups and the Body Mass Index categories of normal, moderately overweight and seriously overweight. In the aspect of Perceived Behavioral Control, the values of its significance can be seen to be greater than .05 , so that it may be concluded that there is no significant value differences between the three groups of subjects, related to their respective aspects.

\section{Discussion}

The authors discovered that it appears that the number of sufferers of overweight amongst the medical staff of the private hospital in Mataram, are far fewer than that of the staff with normal bodily weight, This indirectly indicates an awareness among the hospital staff of the need to watch their weight.

This awareness is very important; self-awareness will support these people to manifest what is considered to be correct behavior. In this case, awareness of the need to watch bodily weight will support the emergence of beneficial eating behavior, or the safeguarding of eating patterns (Goukens, Dewitte, \& Warlop,
Table 8

Results of Reliability Testing of the Measurement Instruments

\begin{tabular}{lccc}
\hline \multicolumn{1}{c}{ Aspects } & $\begin{array}{c}\text { Total } \\
\text { Items }\end{array}$ & CITC & $\begin{array}{c}\text { Alpha- } \\
\text { Cronbach }\end{array}$ \\
\hline Intention & 3 & $.937-.964$ & .977 \\
ATB & 6 & $.921-.983$ & .989 \\
SN & 4 & $.465-.937$ & .909 \\
PBC & 12 & $.188-.644$ & .823 \\
\hline
\end{tabular}

Note. $\quad \mathrm{ATB}=$ Attitude Toward Behavior; $\mathrm{SN}=$ Subjective Norms; $\mathrm{PBC}=$ Perceived Behavioral Control

Table 9

Normality Test Result

\begin{tabular}{lrrc}
\hline \multicolumn{1}{c}{ Aspects } & \multicolumn{1}{c}{$M$} & \multicolumn{1}{c}{$S D$} & $\begin{array}{c}\text { Kolmogorov- } \\
\text { Smirnov }\end{array}$ \\
\hline Intention & 9.85 & 6.73 & .001 \\
ATB & 18.81 & 12.95 & .001 \\
SN & 16.52 & 8.56 & .900 \\
PBC & 43.67 & 14.78 & .029 \\
\hline Note. ATB = Attitude Toward Behavior; SN $=$ Subjective Norms; PBC $=$ \\
Perceived Behavioral Control ; sig =.05 (normal)
\end{tabular}

Table 10

Homogeneity Test Result

\begin{tabular}{lcc}
\hline \multicolumn{1}{c}{ Aspects } & Sig & \multicolumn{1}{c}{ Notes } \\
\hline Intention & .001 & Non-homogeneous \\
ATB & .000 & Non-homogeneous \\
SN & .034 & Non-homogeneous \\
PBC & .559 & Homogeneous \\
\hline Note. ATB = Attitude Toward Behavior; SN $=$ Subjective Norms; PBC $=$ \\
Perceived Behavioral Control $;$ sig $=.05$ (normal); sig $=.05$
\end{tabular}

Table 11

Results of Kruskal-Wallis

\begin{tabular}{lcc}
\hline \multicolumn{1}{c}{ Aspects } & Sig & Notes \\
\hline Intention & .000 & Difference + \\
ATB & .000 & Difference + \\
SN & .000 & Difference + \\
PBC & .263 & No Difference \\
\hline Note. ATB = Attitude Toward Behavior; SN $=$ Subjective Norms; PBC $=$ \\
Perceived Behavioral Control $;$ sig $=.05$
\end{tabular}

2010). Besides this, there is also research stating that there is a significant positive relationship between the awareness of Attitude Toward Behavior (Aminrad, Zakariya, Hadi, \& Sakari, 2013). This relationship is possibly the reason for the high Attitude Toward Behavior score in the overweight subject groups (moderately overweight and seriously overweight).

Based upon average scores, it may be seen that there are categorical differences between subject groups, in the aspect of Intention. Intention, on the basis of the theory, indicates the readiness of a person to per- 
Table 12

Ideal Norms of Aspects

\begin{tabular}{|c|c|c|c|c|}
\hline \multicolumn{2}{|c|}{ Category } & \multicolumn{3}{|c|}{ Ideal Norms } \\
\hline \multicolumn{5}{|l|}{ Intention } \\
\hline & Very High & 13.2 & $\geq X$ & \\
\hline & High & 20.4 & $\geq X>$ & 13.2 \\
\hline & Moderate & 27.6 & $\geq X>$ & 20.4 \\
\hline & Low & 34.8 & $\geq X>$ & 27.6 \\
\hline & Very Low & & $X>$ & 34.8 \\
\hline
\end{tabular}

Attitude Toward Behaviors

$\begin{array}{rrlr}\text { Very High } & 8.8 & \geq \mathrm{X} & \\ \text { High } & 13.6 & \geq \mathrm{X}> & 8.8 \\ \text { Moderate } & 18.4 & \geq \mathrm{X}> & 13.6 \\ \text { Low } & 23.2 & \geq \mathrm{X}> & 18.4 \\ \text { Very Low } & & \mathrm{X}> & 23.2\end{array}$

Subjective Norms

$\begin{array}{rrlr}\text { Very High } & 6.6 & \geq \mathrm{X} & \\ \text { High } & 10.2 & \geq \mathrm{X}> & 6.6 \\ \text { Moderate } & 13.8 & \geq \mathrm{X}> & 10.2 \\ \text { Low } & 17.4 & \geq \mathrm{X}> & 13.8 \\ \text { Very Low } & & \mathrm{X}> & 17.4\end{array}$

Perceived Behavioral

Controls

$\begin{array}{rrll}\text { Very High } & 26.4 & \geq X \\ \text { High } & 40.8 & \geq X> & 26.4 \\ \text { Moderate } & 55.2 & \geq X> & 40.8 \\ \text { Low } & 69.6 & \geq X> & 55.2 \\ \text { Very Low } & & X> & 69.6\end{array}$

form a behavior (Ajzen \& Fishbein, 1980), and, in this case, it is the intention to reduce bodily weight. Table 13 shows that the groups suffering overweight indicated an intention to reduce body weight which is higher than that of those in the group of subjects with normal weight. Besides this, in accord with the Theory of Planned Behavior (Ajzen \& Fishbein, 1980), the size of the values of Intention indicate that the overweight groups have the readiness to, and a quite good possibility of success in, reducing their bodily weight (Iffah, 2011; Mappaompo, 2010; McConnon et al., 2012; Psouni, Hassandra, \& Theodorakis, 2016; Sargowo \& Andarini, 2011), so that the hospital can give support by providing an exercise programme or one for regulating eating patterns, assisted by the oversight of hospital nutrition experts.

Based upon the Theory of Planned Behavior, Intention will be boosted by the other aspects, i.e., those of Attitude Toward Behavior, Subjective Norms, and Perceived Behavioral Control. Amongst those aspects, the Perceived Behavioral Control categories from the three groups did not show the existence of any diffe- rences. This indicates roughly that this aspect did not have much influence on the groups of subjects in this research. The three groups all actually felt able to control their eating behavior.

The moderately and seriously overweight groups indicated differences in attitude towards the reduction of bodily weight, compared to the normal weight group. The moderately and seriously overweight groups showed a positive attitude towards behavior aimed at reducing bodily weight. This meant that at variance to the normal weight group, the moderately and seriously overweight groups felt it was necessary to reduce their bodily weight.

Theoretically, this attitude might have been caused by influence from other aspects. In this case, the aspect of Subjective Norms was an influence on the difference in attitude regarding weight-reduction behavior. Subjective Norms is the perception of a person regarding social pressures manifested by others, particularly by significant others, which prompts a person to produce a behavior. From the data obtained, it could be seen that, at variance with those in the normal weight group, the people in the overweight group have the meta-perception that those around them believe they need to reduce their weight.

On the basis of the Theory of Planned Behavior, it is said that the Intention of a person to perform a particular behavior will be prompted by Subjective Norms, Attitudes Toward Behavior, and Perceived Behavioral Control. Further to this, several pieces of research have found that of the three factors, the Attitude Toward Behavior and the Perceived Behavioral Control factors have greater relationships in determining the intention to perform a behavior (Gronhoj, Bech-Larsen, Chan, \& Tsang, 2012; Psouni et al., 2016; Truong, 2009). Nonetheless, in this research, it could be seen that there was no significant difference in the Perceived Behavioral Control scores of the three groups. Although this is the case, it could also clearly be seen that there were differences in the Intention to reduce bodily weight, between the three groups. The group of those in the Body Mass Index categories of above normal weight showed a more positive response, regarding Intention to reduce bodily weight. Besides this, in this research it was also found that subjective norms showed very significant differences. This indicated that, in this research, it was actually the aspects of Subjective Norms and Attitude Toward Behavior which were the determinants of the occurrence of the differences, in the values of Intention in the subject groups.

The differences concerning the influence between Subjective Norms and Perceived Behavioral Control 
Table 13

Categorical Averages of Groups, Based upon Ideal Norms of Aspects

\begin{tabular}{llcc}
\hline \multicolumn{1}{c}{ Aspect } & & Mean & Category \\
\hline Intention & Normal & 13.9 & High \\
& Overweight & 5.4 & Very High \\
& Moderately overweight & 5.8 & Very High \\
& Seriously overweight & 5 & Very High \\
& & & \\
Attitude Toward Behaviors & Normal & 26.7 & Very Low \\
& Overweight & 10.15 & High \\
& Moderately overweight & 12.2 & High \\
& Seriously overweight & 8.1 & Very High \\
Subjective Norms & & & \\
& Normal & 21.4 & Low \\
& Overweight & 11.15 & Moderate \\
& Moderately overweight & 12.7 & Moderate \\
& Seriously overweight & 9.6 & High \\
Perceived Behavioral Controls & Normal & 47.4 & Low \\
& Overweight & 39.55 & High \\
& Moderately overweight & 40.1 & High \\
& Seriously overweight & 39 & High \\
\hline
\end{tabular}

in these subject groups were possibly largely brought about because of cultural influences. It is necessary to remember that the related pieces of research used for comparison were those whose subjects were from a Western cultural background, whilst, in this research, the subjects were Asians (Indonesians). According to existing research (Ando, 2016), at variance to Western culture, Asian culture is very much influenced by subjective norms. This is brought about by Asian culture greatly prioritizing the values of interpersonal relationships, whereas Western culture tends more to have the characteristics of individualism, and to prioritize independence. The same thing is found in various pieces of research related to differences in the influence of Subjective Norms between groups of subjects of Asian and of European cultural backgrounds (Abrams, Ando, \& Hinkle, 1998; Ando, 2016).

\section{Limitations and Recommendations}

The shortcoming in this research was the data collection process, which was less than effective, and not closely controlled. Besides this, the difficulties in the field were the shifts worked by different employees. Shortages of time and deficiencies in coordination between the researchers and the hospital (which more prioritized caring for patients than for its medical personnel) caused the researchers to decide to use the incidental sampling method. With this method, the researchers felt less than able to control the population well, so that quite a lot of surveys, whose completion did not fulfill the requirements, were unable to be used. It is recommended that the hospital management hold a meeting concerning the importance of the subjective norms of the groups of participants/subjects, to support the development of a desire to reduce excessive bodily weight. This can be done by involving the people considered important by the overweight sufferers (significant others), by sowing the perception of obesity, so that, as people considered important, they may be able to direct informal discussions concerning the bodily weight of their fellows, who are suffering overweight, and to support these sufferers.

\section{Conclusion}

It is appropriate to suppose that local culture has a role in determining the level of Intention to reduce bodily weight of the medical personnel suffering overweight and obesity in this hospital, in Mataram,. This can be seen in the variance results, compared to those of research participants coming from the West, particularly in the aspects of Attitude Toward Behavior and Subjective Norms. In the West, it is the aspects of Attitude Toward Behavior and Perceived Behavioral Control which are normally dominant. As has been stated above, the Intention of the subjects, more influenced by the aspect of subjective norms, indicates that the form of treatment, involving the significant others of the subject, may have a more promising/prospective 
impact, especially recalling that the sufferers of overweight and obesity demonstrated a readiness to reduce bodily weight through adopting a healthy pattern of living. This optimism would be appropriately manifested in the organization of intervention programmes to assist raising the motivation of the sufferers of overweight and obesity to maximize efforts to improve their health levels. Involvement and concern from the hospital management is greatly hoped for, for the success of this programme, which, in turn, will have a positive impact on the continuity of the service from the medical staffs towards their patients.

\section{References}

Abrams, D., Ando, K., \& Hinkle, S. (1998). Psychological attachment to the group: Cross-cultural differences in organizational identification and subjective norms as predictors of workers' turnover intentions. Personality and Social Psychology Bulletin, 24, 1027-1039.

Ajzen, I. (2006). Theory of planned behavior. Retrieved from http://people.umass.e- du/aizen/tpb.diag. html\#null-link

Ajzen, I., \& Fishbein, M. (1980). Understanding attitudes and predicting social behavior. Englewood Cliffs, NJ: Prentice Hall.

Aminrad, Z., Zakariya, S. Z. B. S., Hadi, A. S., \& Sakari, M. (2013). Relationship between awareness, knowledge and attitudes towards environmental education, among secondary school students in Malaysia. World Applied Sciences Journal, 22(9), 1326-1333. https://doi.org/10.5829/idosi.wasj.2013. 22.09.275

Ando, K. (2016). Cultural differences on the role of norms on environmental behavior. Paper presented at the Understanding The Role of Cultural Contexts on Environmentalism, Pacifico Yokohama Conference Center, 3F 312.

Annisa, N., Indriasari, R., \& Yustini. (2014). Persepsi remaja tentang obesitas dan perilaku makan terkait obesitas di SMA Katolik Cendrawasih Makasar. Retrieved from http://repository.unhas.ac.id/bitstream/ handle/123456789/11327/NURUL\%20ANNISA $\% 20 \mathrm{~K} 21110106$.pdf? sequence $=1$

Arisman, M. B. (2004). Gizi dalam daur kehidupan (2nd ed.). Jakarta: Penerbit Buku Kedokteran EGC.

Aucott, L., Pooblan, A., Smith, W. C. S., Avenell, A., Jung, R., \& Broom, J. (2005). Effects of weight loss in overweight/obese individuals and long-term hypertension outcomes. Hypertension, 45, 1035-1041.
Bourne, P. A., Glen, L. V., Laws, H., \& Kerr-Campbell, M. D. (2010). Health, lifestyle and health care utilization among health professionals. Health, 2(6), 557-565.

Delima, V. S. (2013). Kecemasan memeroleh pasangan hidup pada wanita dewasa awal, yang mengalami obesitas. Universitas Gunadarma, Jakarta. Retrieved from http://publication.gunadarma.ac.id/bitstream/ 123456789/6934/1/Power\%20Point\%20Sidang.pdf

Elovainio, M., Shipley, M. J., Ferrie, J. E., Gimeno, D., Vahtera, J., Marmot, M. G., \& Kivimaki, M. (2009). Obesity, unexplained weight loss and suicide: The original Whitehall study. Journal of Affective Disorders, 116(3), 218-221.

Fatimah, N. (2014). Perbedaan antara obesitas dan non-obesitas terhadap kejadian depresi pada ibu rumah tangga di daerah Kelurahan Cililitan, Jakarta Timur. Universitas Islam Negeri Syarif Hidayatullah. Retrieved from http://repository.uinjkt.ac. $\mathrm{id} /$ dspace/bitstream/123456789/26119/1/Nurul\% 20Fatimah-fkik.pdf

French, S. A., Story, M., \& Perry, C. L. (1995). Selfesteem and obesity in children and adolescents: A literature review. Obesity Research, 3, 479-490.

Gibbons, G. H. (2013). What are the health risks of overweight and obesity? Retrieved from https://www. nhlbi.nih.gov/health/health-topics/topics/obe/risks

Ginting, M. R. B. (2011). Hubungan harga diri dengan kemampuan aktualisasi diri remaja putri dengan obesitas di SMA Negeri 1 Sei Bingai. Universitas Sumatera Utara, Medan. Retrieved from http://repo sitory.usu.ac.id/bitstream/123456789/27522/6/Ab stract.pdf

Goukens, C., Dewitte, S., \& Warlop, L. (2010). How your client's private self- awareness influences choice. Keller Center for Research report (pp. 1-5). Baylor University. Waco, TX.

Gronhoj, A., Bech-Larsen, T., Chan, K., \& Tsang, L. (2012). Using theory of planned behavior to predict healthy eating among Danish adolescents. Health Education \& Behavior, 113(1), 4-17.

Hermawan, G. (1991). Komplikasi obesitas dan usaha penanggulangannya. Cermin Dunia Kedokteran, 68, 39-41.

Hidayati, S. N., Irawan, R., \& Hidayat, B. (2009). Obesitas pada anak [Online]. Divisi Nutrisi dan Penyakit Metabolik, Ilmu Kesehatan Anak, Fakultas Kedokteran Universitas Airlangga.

Horvath, J. D. C., Castro, M. L. D. D., Kops, N., Malinoski, N. K., \& Friedman, R. (2014). Obesity coexists with malnutrition? Adequacy of food consumption by severely obese patients to dietary reference intake 
recomendations. Nutrition in Hospitals, 29(2), 292299.

Ibarra, J. (2009). Obesity and cardiovascular disease. The Journal of Lancaster Hospital, 4, 130-133.

Iffah, N. (2011a). Strategi penanganan obesitas secara aman dan efektif. Jurnal Sains Med, 3, 9-15.

The International Classification of adult underweight, overweight and obesity according to BMI. (n.d.). Retrieved from http://apps.who.int/bmi/index.jsp? introPage=intro_3.html

Istiwamah, N., Sirajuddin, S., \& Indriasari, R. (2013). Hubungan pola hidup sedentarian dengan kejadian obesitas sentral pada pegawai pemerintah di kantor Bupati, Kabupaten Jeneponto. Universitas Hasanuddin, Makasar. Retrieved from http://repository.unhas. ac.id/bitstream/handle/123456789/5671/Jurnal\%2 OIstiqamah\%20MKMI.pdf?sequence $=1$

Jean-Louis, G., Zizi, F., Clark, L. T., Brown, C. D., \& McFarlane, S. I. (2008). Obstructive sleep apnoea and cardiovascular disease: Role of the metabolic syndrome and its component. Journal of Clinical Sleep Medicine, 4(3), 261-272.

Kotchen, T. A. (2010). Obesity-related hypertension: Epidemology, patophysiology, and clinical management. American Journal of Hypertension, 23, 11701178.

Kristina, D. (2010). Hubungan kebiasaan makan dan aktifitas fisik dengan tingkat kegemukan pada pedagang sayur di lingkungan XIII, Kelurahan Kwala Bekala, Medan, Tahun 2010. Universitas Sumatera Utara, Medan. Retrieved from http://repository.usu. ac.id/bitstream/handle/123456789/21087/Cover.p df? sequence $=8$

Kumar, A. (2012). Factors associated with obesity in children. International Journal of Human Science, 9(2), 805-814.

Leung, R. S. T., \& Bradley, T. D. (2001). Sleep apnea and cardiovascular disease. American Journal of Respiratory and Critical Care Medicine, 164, 21472165.

Manurung, N. K. (2008). Pengaruh karakteristik remaja, genetik, pendapatan keluarga, pendidikan ibu, pola makan, dan aktifitas fisik, terhadap kejadian obesitas di SMU RK Tri Sakti Medan. Universitas Sumatera Utara, Medan. Retrieved from http:// repository.usu.ac.id/bitstream/handle/123456789/ 6708/ 09E02213.pdf?sequence $=1$

Mappaompo, M. A. (2010). Obesitas dan olahraga. Jurnal ILARA, 1, 10-16.

McConnon, A., Raats, M., Astrup, A., Bajzova, M., Handijeva-Darlenska, T., Lindroos, A. K., ... Shepherd, R. (2012). Application of the theory of planned be- havior to weight control in an overweight cohort: Results from a pan-European dietary interventon trial. Retrieved from http://epubs.surrey.ac.uk/76 3998/1/McConnon\%20(2012)\%20Application\%2 0of\%20the $\% 20$ Theory\%20of\%20Planned\%20Be haviour\%20to\%20weight $\% 20$ control $\% 20 \mathrm{in} \% 20 \mathrm{a}$ n\%20overweight $\% 20$ cohort.\%20results\%20from $\% 20 \mathrm{a} \% 20$ panEuropean\%20dietary\%20interventi on\%20trial\%20(DiOGenes).\%20Appetite.pdf

Moleres, A., Ochoa, M. C., Rendo-Urteaga, T., MartinezGonzalez, M. A., Julian, M. C. A. S., Martinez, J. A., \& Marti, A. (2012). Dietary fatty acid distribution modifies obesity risk linked to the rs 9939609 polymorphism of the fat mass and obesity-associated gene in a Spanish case-control study of children. British Journal of Nutrition, 107(4), 533-538. https:// doi.org/10.1017/ S000 7114511003424.

Nowrouzi, B., McDougall, A., Gohar, B., NowrouzKia, B., Casole, J., \& Ali, F. (2015). Weight bias in the workplace: A literature review. Occupational Medicine and Health Affairs, 3, 206. https://doi.org/ 10.4172/2329-6879. 1000206

Octari, C., Liputo, N. I., \& Edison. (2014). Hubungan status sosial ekonomi dan gaya hidup dengan kejadian obesitas pada siswa SD Negeri 08 Alang Lawas, Padang. Jurnal Kesehatan Andalas, 3, 131-135.

Olsen, M. F., Wiklund, M., Lonroth, H., \& Olbers, T. (2012). Respiratory function in super-obese patients before and after bariatric surgery - A randomised controlled trial. The Open Obesity Journal, 4, 28-34.

Ondicho, Z. M., Omondi, D. O., \& Onyango, A. C. (2016). Prevalence and socio-demographic factors associated with overweight and obesity among healthcare workers in Kisumu East Sub-County, Kenya. American Journal of Medicine and Medical Science, 6(3), 66-72.

Onyike, C. U., Crum, R. M., Lee, H. B., Lyketsos, C. G., \& Eaton, W. W. (2003). Is obesity associated with major depression? Results from the third national health and nutritional examination survey. American Journal of Epidemiology, 158(12), 11391147.

Oxford Dictionary of English (3rd ed.). (2010). Oxford University Press.

Parameswaran, K., Todd, D. C., \& Soth, M. (2006). Altered respiratory physiology in obesity. Canadian Respiratory Journal, 13(4), 203-210.

Pedoman praktis memantau status gizi orang dewasa. (2011). Retrieved from gizi.depkes.go.id/wp-con tent/uploads/2011/10/ped-praktis-stat-gizi-dewasa. doc 
Prentice, A. M. (2006). The emerging epidemic of obesity in developing countries. International Journal of Epidemiology, 35, 93-99.

Psouni, S., Hassandra, M., \& Theodorakis, Y. (2016). Exercise and healthy eating intentions and behaviors among normal weight and overweight/obese adults. Psychiatric Clinics of North America, 7, 598-611.

Puhl, R. M., \& Heuer, C. A. (2010). Obesity stigma: Important consideration for public health. American Journal of Public Health, 100(6), 1019-1028.

Putra, H. M. (2011). Gambaran tingkat pengetahuan mengenai obesitas dan kejadian obesitas pada mahasiswa Fakultas Kedokteran USU angkatan 2007 dan angkatan 2010 di Medan, tahun 2010. Retrieved from http://repository.usu.ac.id/bitstream/1234567 89/25595/5/Chapter\%20I.pdf

Putri, R. (2012). Hubungan obesitas dengan gambaran citra tubuh pada mahasiswa Fakultas Ilmu Pengetahuan Budaya Universitas Indonesia (FIB UI). Universitas Indonesia. Retrieved from http://lib.ui.ac.id/ file?file=digital $/ 20312640-S \% 2043155-$ Hubungan $\%$ 20obesitas-full\%20text.pdf

Rabec, C., Ramos, P. d. L., \& Veale, D. (2011). Respiratory complications of obesity. Archivos de Bronconeumologia (English Edition), 47(5), 252-261.

Roberts, R. E., Deleger, S., Strawbridge, W. J., \& Kaplan, G. A. (2003). Prospective association between obesity and depression: Evidence from the Alameda County Study. International Journal of Obesity, 27, 514-521.

Sargowo, D., \& Andarini, S. (2011b). The relationship between food intake and adolescent metabolic syndrome. Jurnal Kardiologi Indonesia, 32(1), 14-23.

Sarwer, D. B., Thompson, J. K., \& Cash, T. F. (2005). Body image and obesity in adulthood. Psychiatric Cli- nics of North America, 28, 69-87.

Schwartz, A. R., Patil, S. P., Laffan, A. M., Polotsky, V., Schneider, H., \& Smith, P. L. (2008). Obesity and obstructive sleep apnoea. American Thoracic Society, 5(2), 185-192.

Sediaoetama, A. D. (2008). Ilmu gizi untuk mahasiswa dan profesi. Jakarta: Dian Rakyat.

Simajuntak, D. L., \& Siregar, A. R. (2012). Hubungan penerimaan diri dengan kompetensi sosial pada remaja obesitas. Universitas Sumatera Utara, Medan. Retrieved from http://fpsi.mercubuana-yogya.ac.id/ wp-content/uploads/ 2012/06/Devi-Lestari-AdeRahmawati-Remaja-Obesitas.ok_.pdf

Skelding, K. A., Gerhard, G. S., Vlachos, H., Selzer, F., Kelsey, S. F., Chu, X., . . Kip, K. E. (2010). Association of an INSIG2 obesity allele with cardiovascular phenotypes is gender and age dependent. BMC Cardiovascular Disorders, 10(46), 1-7. https:// doi.org/10.1186/1471-2261-10-46

Sunendar, D. (2016). Kamus Besar Bahasa Indonesia Daring. Retrieved from https://kbbi.kemdikbud.go. id/entri/obesitas

Sutjijoso, A. R., \& Zarfiel, M. (2009). Harga diri dan prestasi belajar pada remaja yang obesitas. Jurnal Psikologi, 3(1), 68-75.

Tarigan, N., Hadi, H., \& Julia, M. (2005). Hubungan citra tubuh dengan status obesitas, aktifitas fisik dan asupan energi remaja SLTP di Kota Yogyakarta dan Kabupaten Bantul. Jurnal Gizi Klinik Indonesia, 1 (3), 130-136.

WHO (n.d.). International Classification of adult underweight, overweight and obesity according to BMI. New York, NJ: World Health Organization. Retrieved from http://apps.who.int/bmi/index.jsp?intro Page=intro_3.html 